\title{
General Motors' other franchise system: creating an effective distribution model for Frigidaire
}

Article

Accepted Version

Scott, P. (2020) General Motors' other franchise system:

creating an effective distribution model for Frigidaire. Business History, 64 (1). pp. 183-200. ISSN 1743-7938 doi:

https://doi.org/10.1080/00076791.2020.1714594 Available at https://centaur.reading.ac.uk/88499/

It is advisable to refer to the publisher's version if you intend to cite from the work. See Guidance on citing.

To link to this article DOI: http://dx.doi.org/10.1080/00076791.2020.1714594

Publisher: Taylor \& Francis

All outputs in CentAUR are protected by Intellectual Property Rights law, including copyright law. Copyright and IPR is retained by the creators or other copyright holders. Terms and conditions for use of this material are defined in the End User Agreement.

www.reading.ac.uk/centaur 
Central Archive at the University of Reading

Reading's research outputs online 


\title{
General Motors' other franchise system: creating an effective distribution model for Frigidaire
}

\author{
Peter Scott, \\ IBS, Henley Business School at the University of Reading, \\ Whiteknights, Reading, \\ Great Britain, RG6 6UD \\ p.m.scott@ reading.ac.uk
}

JEL Codes: L140; L110; N82

Acknowledgements. Thanks are due to the Centre for Business History, Stockholm, Sweden; Electrolux AB; Hagley Museum Library \& Archives; Kettering University Archives; and Wright State University Library, Special Collections and Archives, for access to sources. Andrew Hull, Rajneesh Narula, Karina Pavlisa, James T. Walker, and two anonymous referees provided valuable comments on earlier drafts. Any errors are mine. 


\title{
General Motors' other franchise system: creating an effective distribution model for Frigidaire
}

Keywords: Franchising; Consumer durables; Hybrid business forms; Distribution; Refrigerators

\begin{abstract}
Using a case-study of General Motors' Frigidaire division, this study shows that differences in market conditions for refrigerators and cars, together with the weaker asset specificity of dealers' physical and other capital, made the opportunistic model used for its auto division impracticable for refrigerators. Frigidaire instead focused on developing symbiotic relationships, based on licensing not only the product and brand name, but also a sophisticated package of business services and training - to encourage dealer conformity and "buy-in" to their formal and informal control systems. Informal controls are shown to have been crucial to incentive alignment and knowledge transfer, underpinned by a vigorous socialization strategy, to build trust and social control and cohesion. This strategy succeeded in getting franchisees and their employees to view themselves as part of the Frigidaire organisation and created the necessary flexibility for Frigidaire's network to rapidly respond to changing market and competitive conditions during the 1930s.
\end{abstract}

\section{Introduction}


Inter-war America witnessed a dramatic expansion in consumer durables diffusion, partly owing to manufacturers' success in developing distribution systems that provided national market coverage. These typically involved "hybrid" business forms, between hierarchies and markets, mainly based on some variant of franchising. Franchising has been relatively neglected in the business history literature, with a few notable exceptions (e.g. Clarke, 2003; Lamoreaux, Raff, and Temin, 2003; Tedlow, 1990). Meanwhile the business and management literature on franchising mainly dates from the late 1970s and is characterised by an evolutionary model involving two distinct franchise systems: "traditional" and "business format." Traditional franchising involves a manufacturer franchising downstream activities to contractually-bound independent firms (typically retailers and/or distributors) which receive only rudimentary services from the franchisor. Then, more recently, the emergence of the "business format" franchising model is said to have introduced more comprehensive and sophisticated packages of business services for franchisees (Rubin, 1978; Lafontaine 1992; Lafontaine and Slade, 1997; Barthelemy, 2008).

This study shows that even in the 1920s some franchising systems included the provision of sophisticated portfolios of business services (including training), using the example of General Motors' Frigidaire division. Moreover, during this period Frigidaire developed systems and routines that overcame many of the problems identified in the modern franchising literature. For example, a vigorous socialization strategy was used to align franchisor and franchisee incentives, overcome the limitations of formal controls, and facilitate the transmission of tacit and complex knowledge. This strategy also increased the flexibility of Frigidaire's network to respond to changing market or competitive conditions, without having to renegotiate formal contracts.

The paper first provides a brief overview of the types of distribution systems developed by early consumer durables' manufacturers and how these varied according to 
product, market, and competitive conditions. It then explores why General Motors (GM) developed a radically different approach to franchising its refrigerators to the opportunistic strategy that of its auto division (Williamson: 1988; 1991; 2003). There follows an in-depth analysis of Frigidaire's more symbiotic franchise system. The provision of business services and training, together with a strategy of socializing franchisee employees to identify as being members of the Frigidaire organization, are shown to have generated a level of retailer "buyin" that could not have been achieved solely using the coercive strategy of its auto division. Finally, the article discusses how Frigidaire's strategy provided the flexibility to respond to changing market conditions during the 1930s.

\section{Alternative routes to achieving nationwide market coverage}

There has been significant recent research on the distribution and marketing of interwar consumer durables, including automobiles (Clarke, 2003; Tedlow, 1990); radios (Scott and Walker, 2016); vacuums (Scott, 2019); and washing machines (Scott, forthcoming). In all cases the Chandler (1990: 28-31) model of ensuring high throughput through forward integration into distribution, to control the flow of outputs via managerial hierarchies, is not consistent with the actual methods used to keep sales in line with production. Instead, manufacturers generally developed hybrid forms, which substituted the "command relationship" of managerial hierarchies with long-term contractual relationships that provided incentives and credible threats to ensure dealer conformity (Lamoreaux, Raff, and Temin, 2003, 405-7).

Vacuum cleaner firms, which were particularly reliant on home demonstration to sell their products, mainly used the "resale system", pioneered by Hoover. Under this system door-to-door salesmen were nominally working for some local dealer, but were trained, supervised, and paid by the manufacturer. The store received a lower commission than the 
typical price mark-up (15 percent, rather than the customary 33.3 percent), with the balance used to pay the salesman and his associated costs. The store's role was limited to providing sales leads, allowing the salesman to demonstrate in-store and call on prospects using its name; stocking inventory; providing the retail credit; and undertaking local advertising (Scott, 2019, 323-4). Given that the salesmen were directly controlled by Hoover, its field staff, rather than the dealers they collaborated with, mainly managed the salesforce.

Washing machine and radio manufacturers typically selected strong independent retailers who were offered exclusive franchised territories. They were required to provide after-sales service and credit and participate in special promotions, local advertising, and door-to-door selling, while giving the manufacturer's brand greater prominence than the others they stocked (particularly in radio, where exclusive representation was rare, as the public liked to see several different brands). Field sales forces were developed to monitor the franchisees, ensuring that they met the firm's requirements and did not engage in practices such as price-cutting or infringing other retailers' territories. They also incentivised dealers via co-operative advertising; promotions; competitions; assistance with instalment selling; subsidies for trade-ins; sales training and (for washers) sometimes provided door-to-door salesmen on the resale system (Scott and Walker 2016; Scott, forthcoming).

However, in some respects the refrigerator was a harder sell than these other durables. It was not suitable for home demonstration, had a close substitute (the ice box) and was substantially more expensive to buy and run than a vacuum, washer, or radio. Moreover, developing a refrigerator for home use which would not need frequent maintenance proved a very difficult technical task, delaying significant diffusion of mechanical refrigerators until the mid-1920s (see Figure 1). Rapidly achieving national market coverage, for an essentially "new" and very expensive product constituted a major challenge, which required the 
development of particularly sophisticated franchise relationships, as the following case-study demonstrates.

\section{[Figure 1 near here]}

\section{Methodology}

This paper is part of a broader study of the factors determining competitive success in the inter-war U.S. household durables sector (Scott, 2017; 2019; forthcoming; Scott and Walker, 2016). Frigidaire was chosen for this case-study as it was the refrigerator market leader; it used franchising as a key element of its expansion strategy; and it has bequeathed particularly rich and comprehensive archival resources (with an extensive archival collection at Kettering University, Flint, Michigan, together with a smaller archive at Wright State University, Dayton, Ohio). The Kettering archive provided particularly valuable information on all aspects of Frigidaire's inter-war activities, with extensive documentation such as internal reports, marketing materials, communications with franchisees, inter-departmental correspondence, and strategic plans.

In addition to triangulation between the extensive sources in the two Frigidaire archives, further triangulation was undertaken with four types of external sources, to mitigate potential problems arising from materials specifically selected for preservation by Frigidaire. These include: archival and other evidence regarding Frigidaire's main rivals, GE and Serval; surviving archival evidence from other leading household durables firms, such as Easy Washing Machine Co. and Maytag, to examine the extent to which Frigidaire's practices were typical of the broader sector; examination of every issue of the industry's main trade journal, Electrical Merchandising, for the period under discussion; and a systematic analysis of contemporary and historical secondary literature on Frigidaire and the wider household durables sector (including contemporary U.S. government investigations). 
The following case broadly follows the "historical cognizance" approach, outlined by Kipping and Usdiken (2014: 543-3), in seeking to test and, potentially, modify theory through the use of a historical case, while also recognising the historical context of the case and the specific contingencies of the sector and its market. The analysis focuses on how the solutions Frigidaire developed suited the specific context of the refrigerator market, while not necessarily representing an ideal type solution for other durables with different market characteristics (Maclean, Harvey, and Clegg, 2017: 477; Perchard et. al., 2017).

\section{Frigidaire's distribution system}

Frigidaire was chosen for this company case-study as it was the inter-war refrigerator market leader and thus constitutes an "extreme case" (Flyberg, 2006) of enduring market success in household durables. Enduring success was by no means typical for household durables firms in this era; for example, three of the four leading radio manufacturers of the late 1920s failed to survive as significant players in the market by the mid-1930s (Scott, 2017), while Frigidaire's main rivals in the late 1920s, General Electric's (GE's) refrigerator department, and Servel, also experienced severe problems during the 1930s. ${ }^{1}$ Mechanical refrigerators constituted the most important household durable of the 1930s, with electrical refrigerators comprising some 40 percent of domestic electrical appliance sales by value (excluding lamps) in $1936 .{ }^{2}$ Frigidaire was both the household and commercial (i.e. commercial storage, shop refrigeration, etc.) refrigerator market leader for most years from the early 1920 s to 1941 . This article focuses on its household refrigerator sales.

Frigidaire has its origins in the personal acquisition of the struggling Guardian Refrigerator Co. by GM's President, W.C. Durant, in 1918. Durant justified diversifying into refrigeration in terms of product synergies, "What are refrigerators but boxes with motors" (Gantz, 2015: 99). However, despite some limited R\&D spillovers, strong synergies between 
car and refrigerator production proved illusory. As GM President Alfred P. Sloan

acknowledged in the early 1930s, Frigidaire "had nothing to do with the automobile industry" (Tedlow, 1990: 311).

Critically, refrigerators lacked the strong technical economies that constituted impregnable barriers to entry in the volume car market. For example, when GE entered the domestic refrigerator market in 1927, the executive in charge of the project, T.K. Quinn, correctly estimated that they required an annual output of only 50,000 units to be price competitive with Frigidaire and its nearest rival, Kelvinator (Quinn, 1953: 88). Minimum efficient scale appears to have fallen substantially during the 1930s, owing to the standardisation of parts produced by third party suppliers, which led to considerable market entry, with some new entrants - such as Sears Roebuck - undercutting the prices of the leading brands (Anon. 1940: 104). Nevertheless, Frigidaire experienced strong long-term growth in both domestic refrigerator unit and dollar sales up to 1941 and remained the market leader (see Table 1), despite significant falls in market share during the price-wars of 1931-32 and 1937-9 (United States, Temporary National Economic Committee, 1940: 131-4).

\section{[Table 1 near here]}

Frigidaire's enduring success was partly based on high R\&D investment, enabling it to develop new product "features" and more fundamental innovations, such as freon refrigerants. By 1941 Frigidaire had some 50 on-going research projects and an engineering staff of 280, 100 of whom worked full-time on product development (Anon., 1941). This R\&D capacity also enabled Frigidaire to respond rapidly to competitors' innovations. For example, the development of much quieter refrigerators, by Servel in 1926 and GE in 1927, was rapidly countered by Frigidaire's 1928 introduction of the air-cooled compressor. ${ }^{3}$ 
While technical synergies with GM were relatively weak, Frigidaire had another, arguably more important, enduring competitive advantage, which was more closely linked to GM - an outstanding competence in marketing. Frigidaire's ability to extend this marketing capability to its distributors and dealers, largely through mechanisms not specified in the franchise contract, was one of the key factors behind its success.

GM's interwar marketing techniques are regarded as having led the field in consumer durables (Clarke, 2003; Tedlow, 1990). Their Frigidaire project was originally run by R.H. Grant, a talented salesman who had previously worked as Sales Manager for National Cash Register, under John H. Patterson. Patterson was a legendary figure in durables marketing, having pioneered a model for speciality salesmanship which proved extremely influential in sales practice for many leading firms, including IBM and GM's auto divisions (Friedman, 2004: $117-150){ }^{4}$

Like most of its principal competitors, and leading washing machine manufactures such as Maytag (Hoover and Hoover, 1993: 117), Frigidaire operated its distributorships and dealerships mainly via franchisees, who were allocated exclusive territories. Their distribution network essentially followed the vertical franchising system pioneered in the auto sector to achieve "control without ownership" (Tedlow, 1990: 145). This reflected the imperative to rapidly develop national market coverage to deter competitive entry, in what was originally perceived to be a highly oligopolistic sector. Under such conditions decision making has to take account of potential interactions with the strategies of rival firms (Fershtman and Judd, 1987; Slade, 1998). Moreover, according to Quinn (1953: 93-9) there was a tacit understanding among the large firms that price wars should be avoided. When, in 1929, a local price-war did break out between Frigidaire and GE in Pittsburgh, it was rapidly settled by the senior executives of the two companies, leading to price "co-operation" between Frigidaire, G.E., Kelvinator, and - eventually - some other manufacturers. However, 
this may have contributed to Frigidaire and the other big players being slow to react to pricewars instigated by new entrants, which sometimes had a major short-term impact on the incumbents' market shares.

The resource scarcity approach notes that in sectors where national advertising and other scale-intensive assets are key determinants of success, franchising can assist in developing the critical resources required to reap scale economies (Carney and Gedajlovic, 1991; Shane, 1996; Combs et. al., 2004a). One of franchising's attractive features is that it overcomes the managerial capacity constraint on the limits to firm growth in sectors where rapidly gaining national market coverage is essential to achieving scale economies in areas such as marketing and distribution (Penrose, 1959; Shane, 1996). Tedlow (1990: $140 \&$ 174) also argues that rapid development of national company-owned dealer networks would have been prohibitively expensive.

The nature of household durables marketing provided a further imperative for franchising, given the importance of "push selling”, typically by unsolicited door-to-door salesmen. Leading manufacturers marshalled large armies of salesmen; by 1938 Frigidaire's national selling force numbered some $24,000 .{ }^{5}$ In the early 1920 s this was a novel technique for selling consumer durables and therefore required close co-operation between Frigidaire and its retailers to disseminate scarce and largely tacit knowledge. Using franchising, rather than conventional manufacturer - distributor - retailer channels, also enabled durables manufacturers to specify and monitor standards of installation and after-sales service reflecting what was to become a long-term pattern of franchising being concentrated in sectors with a substantial service element, delivered in proximity to the customer (Combs et. al., 2004a). 
Frigidaire divided the USA into regions, each headed by a regional manager. These were in turn sub-divided into zones, comprising three or more district offices. Each zone had an appliance and a commercial manager, a service representative, and a sales engineer. Then came the distributorships, their branches, and the dealerships, which were assigned exclusive territories and given responsibility for repair and maintenance services; stocking parts; recruiting, training, and supervising sales and service staff; and stocking and displaying an adequate product line. ${ }^{6}$

Frigidaire originally intended to use only franchised distributors. However, some franchisees proved under-capitalised (a problem compounded by the highly seasonal nature of the household refrigerator trade, as shown in Figure 2). To solve this, franchised District Offices were supplemented by Frigidaire-owned distributors. ${ }^{7}$ In 1924 there were nine of these, together with around 40 franchised distributorships. ${ }^{8}$ The Depression necessitated an expansion of company-owned distributors, to maintain market coverage in territories where franchisees had gone into liquidation. ${ }^{9}$ Thus, contrary to Oxenfeldt and Kelly's (1969) hypothesis that while firms may favour franchising during their early growth, over time franchisees would become restricted to marginal locations, in Frigidaire's case such locations were more likely to be served by direct operations - owing to the imperative to maintain national market coverage. However, company-owned outlets proved extremely valuable in providing Frigidaire with direct expertise in all stages of distribution, from planning at headquarters to direct interactions with final customers.

\section{[Figure 2 near here]}

Both franchised and company-owned distributors ran their own retail operations, via salesmen operating from their district offices. Some districts also had sub-offices serving as retail outlets, when suitable dealers could not be found. Frigidaire also relaxed their exclusive 
territory approach in larger cities, where the nature of the retail market (particularly strong customer patronage for certain key retailers) required a presence in a number of department, furniture, and other stores. A complex distribution hierarchy thus emerged, consisting, in 1930, of 16 directly owned distributors and 34 franchised distributors, which in turn served 48 "headquarters stores", 34 sub-branches, 336 exclusive dealers, 4,390 non-exclusive dealers, 72 department stores, and 560 power company dealers. ${ }^{10}$

While Frigidaire originally developed this mixed ownership/franchise approach to ensure national market coverage, some contemporary durables firms deliberately opened retail outlets with the sole purpose of gaining retail marketing expertise. For example, one of America's largest washing machine manufacturers, Easy Washing Machine Co., operated fifteen retail stores across the USA by 1927, in order to provide expert advice to their franchised retailers: "They want to... know more about retail selling (through actual experience) than any Dealer they serve." 11

\section{Frigidaire's offer to its franchisees}

Studies of franchising in the early auto sector highlight substantial manufacturer opportunism, shifting costs (including the costs of mistakes, such as overproduction) onto dealers through leveraging the strong power imbalances between manufacturers and retailers (Clarke, 2003; Tedlow, 1990). Exclusive contracts (preventing the sale of rival brands), in a volume car sector comprising only three firms, meant that loss of the franchise typically resulted in liquidation for the dealership. Meanwhile the requirement for franchisee transaction-specific investments in auto dealership premises and plant, unsuitable for most alternative retail uses, imposed significant exit costs (Clarke, 2003). Both Ford and GM are found to have exploited their power over dealers, shifting costs to franchisees through 
strategies such as shipping excess stock; sending models packed with unwanted accessories; and pressing dealers to use manufacturers' finance facilities (Clarke, 2003; Tedlow, 1990).

Conversely, Frigidaire dealers weren't nearly so "locked-in" to their franchisor, making it impractical for Frigidaire to generate quasi-rents via such practices (Chassagnon, 2014). Dealers' key resources and capabilities (a staff of direct salesmen, centrally-located premises, and after-sales service skills) could be transferred either to one of the growing number of rival refrigerator manufacturers or to other durables, such as washing machines or radios. Moreover, many franchisees, such as power companies and appliance dealers, sold multiple product lines and could thus withstand the loss of their Frigidaire franchise. Frigidaire's weaker bargaining power led it to pursue a very different franchising strategy than its GM parent, focusing on building symbiotic relationships. This was underpinned by heavy cumulative investments in sales and marketing assistance to franchised distributors and dealers, capitalising on activities which could be more efficiently developed centrally, owing to scale economies and/or firm-specific assets and capabilities.

Frigidaire sought dealers who were well capitalised; had good standing in their community; experience in speciality selling; responsiveness to Frigidaire's direction; that could both handle salesmen and play fair with them; and who appreciated the importance of good after-sales service and sufficient display space. ${ }^{12}$ Once dealers were signed up, Frigidaire assisted them in organising installation and after-sales service; finding or training a sales supervisor; and hiring and training door-to-door salesmen. ${ }^{13}$

Franchise agreements are relational contracts, with implicit and explicit rights and obligations, which set up incentives and define the boundaries of expected franchisee conformity and autonomy (Bradach, 1997). Frigidaire's agreement was formally a discrete contract (dictated by the franchisor; Combs et. al. 2004b), but, as key elements of the 
franchise relationship were not clearly specified, a significant relational element was also required. Frigidaire's 1933 standard contract was a relatively short, five page, document, with 27 clauses. It included a specified franchise territory, cancellable at any time by either party, with or without cause, and gave Frigidaire the right to change the size of the territory at will. The contract specified that Frigidaire was entitled to inspect the dealer's place of business and audit their records and accounts. ${ }^{14}$ Dealers were obliged to maintain display facilities deemed satisfactory to Frigidaire and carry an adequate stock, while maintaining efficient installation and service facilities. They were also prevented from charging more than Frigidaire's suggested installed prices.

Rapid access to dealers' financial data constituted a powerful formal control mechanism. Following the practice of their GM parent (Chandler, 1962: 145-153), Frigidaire required franchisees to report their stocks, sales, and installations, every 10 days. These figures both fed into Frigidaire's production planning and benchmarked the outlet's performance. As one branch manager told his colleagues in 1928, "In visiting dealer, the Branch Manager should go into detail as regards the dealer's finances and profits and discuss it in a very frank manner." However - despite being specified in the franchise contract - such monitoring was still socially embedded. He continued, "Fortunately I am close enough to most of the dealers... that I can walk into their office and go over the books and accounts... I want to know the inside story of that dealer's ... financial condition... whether he is making money or losing money and if he is, why? "15

In 1930 statistical monitoring was extended to individual salesmen, via Frigidaire's "Supervisory and Sales Activity Accounting Plan" for its “metropolitan" dealers. This provided a practical method of comparing the relative efforts of salesmen within and across dealerships; determining man-power requirements; compiling information regarding the coverage of the dealer's territory, and providing frequent sales, credit, and other data for 
Frigidaire. ${ }^{16}$ This system compelled each level of management to regularly monitor the performance of its subordinate level, while generating the data required by head office and the branch/distributor using only three key forms. ${ }^{17} \mathrm{~A}$ simpler plan was introduced for Frigidaire's "provincial" dealers in smaller towns, where limited local markets required selling Frigidaires alongside other merchandise.

Modern franchise contracts typically include process/outcome controls such as field audits, automated management information systems, and mystery shoppers, to counter opportunism, or the withholding of information that might be useful to the chain (Akremi et. al., 2010). While Frigidaire's contract included similar formal controls, one of the most interesting aspects of its system was the extension of control over activities not specified in the contract - an important aspect of franchising that remains relatively neglected (Ater and Rigbi, 2015).

Codified knowledge management systems, such as Frigidaire's dealer accounting system, typically struggle to capture more diverse knowledge and data that fall outside the system (Turner and Makhija, 2006). Two critical mechanisms for Frigidaire control over elements of the franchise relationship not codified in their contract were the development of an integrated array of services for its franchisees, together with socialisation mechanisms designed to boost trust and social control. These were deeply intertwined, as franchisees' enthusiastic participation in the network's marketing strategy relied on trust that it would raise profits both for Frigidaire and themselves. This was not axiomatic, as theory suggests that if dealers bear all the costs of their own promotional activities they will engage in less promotion expenditure than the manufacturer (who shares in the benefits) would find optimal (Tirole, 1988: 177-179; Scott and Walker, 2016). 


\section{Network knowledge transfer and incentive alignment}

The principal's business practices have been identified as ranking second only to the brand name as the most important resources provided to franchisees (Barthelemy, 2008). Building on the marketing expertise of GM, Frigidaire rapidly developed an integrated marketing and sales strategy, largely based around the (then) novel method of direct, door-todoor, selling. This constituted an effective, but problematic, sales strategy. Recruiting was difficult, as people looked down on direct sales work, while in the 1920s refrigerators were typically sold to prosperous white-collar families, thus requiring a "higher type of salesmen" than for vacuums or washing machines. ${ }^{18}$ Moreover, the industry faced an endemic problem of chronic salesforce turnover, estimated at 350 per cent for Frigidaire in 1929 - thus requiring 42,000 new recruits each year to maintain a salesforce of $12,000 .{ }^{19}$

Frigidaire provided their franchisees with manuals and advice on how to attract and select door-to-door salesmen, while also organising national recruiting drives - such as the 1933 "Everyman get a man" campaign, where salesmen were offered gifts in return for finding new recruits. ${ }^{20}$ Frigidaire also provided salesmen's training, principally via training schools, sales literature, and personal coaching. ${ }^{21}$ The selling formula, broken down into a series of steps, essentially involved getting through the door; making an investigation of the household's refrigeration arrangements, family size, financial position, etc.; making the sales pitch; returning in the evening to make a further pitch to the husband; and closing the sale. ${ }^{22}$

Gaining entry to the home was facilitated by offering something of tangible value to the prospect. Vacuum salesmen offered to clean some of their carpets, while washer salesmen often offered to do the weekly washing (Scott, 2019; forthcoming). Refrigerator salesmen couldn't offer such a service and Frigidaire thus armed them with small gifts, such as the "Magic Shopper" chart, showing the correct positioning of food in any type of mechanical or 
ice refrigerator. This was a particularly useful "door-opener," as the salesman had to see the customer's (typically ice) fridge in order to know which chart it corresponded to. ${ }^{23}$ Another tactic was to claim the salesman was undertaking a "Home Economics Survey" for Frigidaire, which also enabled him to request personal details. ${ }^{24}$ Once inside, their inability to bring the refrigerator to the prospect's home was overcome by using picture albums and an array of other "sales helps" for the demonstration. These even included a portable projector, for showing films regarding Frigidaire products, or the dangers of un/poorly-refrigerated food. ${ }^{25}$

Frigidaire invested intensively in advertising and marketing, in co-operation with their franchisees. Early adverts focused on the health dangers of unrefrigerated food and ice refrigeration (which, they claimed, could not maintain a constant safe temperature). In the 1930s, when the idea of mechanical refrigeration had gained consumer acceptance, there was a growing emphasis on convenience and money-saving benefits, together with the specific advantages of the Frigidaire brand. Conventional advertising ran alongside heavy investments in sales planning and direct mailings, as elements of a marketing strategy primarily based on supporting the door-to-door salesman. ${ }^{26}$

Sales campaigns and materials were generated centrally. Contrary to the common modern franchisor practice of tying franchisees' input purchases at above market prices (Rubin, 1978), Frigidaire generally paid at least part of the cost of the advertising and marketing materials and services offered to dealers, reflecting common practice for consumer durables' manufacturers in this era (Scott and Walker, 2016). For example, Frigidaire provided a direct mailing service to dealers' prospects, paying 78 percent of total costs. ${ }^{27}$ Frigidaire also developed a Home Service organization from 1929, to create customer goodwill by providing participating local dealerships with trained female demonstrators, who spoke to women's clubs and educational bodies, while also developing and distributing recipe books and other customer literature. ${ }^{28}$ 
In addition to on-going marketing activities, Frigidaire invested heavily in periodic special campaigns that relied on dealer participation. These included campaigns to sell refrigeration in winter (when demand what at its lowest, as many people used natural refrigeration, for example by putting food in their cellars), together with campaigns based on novel sales angles. ${ }^{29}$ For example, one particularly successful campaign, instituted in 1935 , targeted lower-income families via the "Meter-Ice Purchase Plan," offering Frigidaires with no down payment and daily payments starting at only $15 \mathrm{c}$ for a basic model (deposited in a meter attached to the Frigidaire, which controlled its operation). ${ }^{30}$

Getting franchisees to "buy in" to Frigidaire's strategy involved aligning the dealers' incentives with those of the company, while "selling" the advantages of their sales formula through a vigorous socialization strategy. Training and on-going "guidance" have been identified as important, if costly, mechanisms to achieve such alignment, especially for elements that could not be completely formalised in the contract (Hendry, 2002) while also constituting important channels for communicating knowledge and disseminating innovation. Training also played further important roles in socializing Frigidaire's franchisees' staff in the norms, expectations, and values of the franchise and in developing a consciousness that they were part of the wider Frigidaire organisation. As one branch manager put it, "We must have their confidence as well as the confidence of the dealer himself and they must be able to believe that they are a part of us and not working merely for a dealer." ${ }^{31}$ Evidence suggests that this approach was successful. For example, a testimonial from a department store franchisee, The Outlet Store, Providence, Rhode Island, noted that their "Frigidaire Department feels that it is a part of two organisations. It is a part of the Outlet Store and a part of Frigidaire as well. The men consider themselves Frigidaire salesmen in every sense of the word." 32 
Psychological ties, strengthened through socialization strategies, have been identified as valuable channels for transferring complex forms of knowledge, especially where that knowledge is non-codified and/or concerns a series of interdependent components (Turner and Makhija, 2006; Hansen, 1999). Trust has been identified as an important control mechanism, mitigating opportunism and encouraging conformity to shared norms, cemented by socialisation processes, including formal social structures (Zucker, 1986; Bradach and Eccles, 1989; Darr, Argote and Epple, 1995; Turner and Makhija, 2006). Such mechanisms can create shared values, attitudes, motivations and perceptions of common interests and goal congruence among the network's staff, through rituals, ceremonies, and symbolic incentives as well as meetings and conventions (Turner and Makhija, 2006).

Competitions, both between franchised dealerships and individual salesmen, constituted an important mechanism for creating an esprit de corps (Frigidaire's standard policy being to pay half the costs of approved competitions). These cemented "franchisee cohesion," defined as “franchisees' inclinations to forge social bonds, help each other, and coordinate their efforts around the chain's tasks and objectives" (Akremi, et. al., 2010: 933). By blending trust and social control, cohesion is said to mitigate franchisee opportunism and foster strongly shared values and norms, based around common interests (Akremi, et. al., 2010).

Competitions and their winners were trumpeted in Frigidaire bulletins to its franchised and directly-employed salesmen. These aimed to inspire greater sales, disseminate information on new sales techniques, keep salesmen up to date with various developments in Frigidaire products and methods, and inform them about new sales drives and competitions, together with celebrating their winners. ${ }^{33}$ Prize-winners received not only monetary incentives, but symbolic ones, such as membership of the "B.T.U. club" for outstanding 
salesmen, who were each given a "diamond studded B.T.U. club pin" to mark them out as members of the sales elite. ${ }^{34}$

Competitions and clubs were advertised, promoted, and celebrated in a series of bulletins and flyers, which also served to further develop employee loyalty, while reinforcing the image of the company as a community or "family" - in effect, "selling" the corporation to its workers (Brown, 2005: 138-9). For example, Frigidaire Field News included reports on sales competitions, leading salesmen, conventions, and the achievements of the sales force, with substantial space being given to the names of salesmen who had won competitions or qualified for club membership. ${ }^{35}$ By discussing individual success in the context of the company's internal culture and sense of community, they helped to strengthen corporate ideology (Biggart, 1989: 85).

Sales conventions were also important channels for socialisation. ${ }^{36}$ Conventions typically mixed business presentations during the day and skits, playlets, and lavish entertainment in the evenings, including episodes of "misrule": ritual events during which workers subverted the hierarchy in controlled settings, such as the ridiculing of corporate aims and objectives (within controlled bounds) (Kwolek-Folland, 1994:161-2; Zunz, 1990, 186). Misrule episodes also sometimes occurred spontaneously. For example, at one early regional Frigidaire convention, too much time was left between the business session and banquet and some drunken salesmen started trying to bomb the tables under the edge of the hall's balcony with heavy glass water carafes (fortunately without injuries). ${ }^{37}$

Such strategies were widely used by other sales-orientated firms (e.g. chain stores), but Frigidaire, together with some of its competitors, extended them to the staff of their franchised dealerships - effectively treating them as part of their organisation. Frigidaire's managers were expected to take an active interest in all aspects of their franchised 
dealerships' management, to ensure that franchisees not only met financial objectives, but also maintained high levels of social cohesion. As one branch manager noted:

It is our duty... to... keep the dealer organization 'pepped' up and in close contact with our company policies. In other words, we believe in looking upon a dealer organization in both sales and service, as though it were our own. Even though they are on the Dealer's pay roll, we feel that we are more or less responsible for their creation and their existence and were we to leave it to the dealer to handle the meetings... the enthusiasm and 'pep' would very quickly ooze out. ${ }^{38}$

\section{Adapting strategy to a changing market}

One potential disadvantage of franchises and other long-term relationships is that they can develop rigidities - becoming isolated from cost and efficiency pressures and making renegotiation in response to changing economic conditions more difficult (Lamoreaux, Raff, and Temin, 2003: 409). Frigidaire faced a major change in market conditions during the 1930s, as the growing reliability and technological maturity of refrigerators transformed them from a specialist sales proposition to an item suitable for "over the counter" retailing. As a 1935 Frigidaire internal report noted, "What began as a specialty business changed rapidly to a merchandising activity... It was a natural step for the merchandising type of store such as department stores, utilities, and furniture stores to sell electric refrigerators since many of

them were already selling electric washers, ranges, and other household appliances." ${ }^{39}$ Such outlets accounted for 42.2 percent of Frigidaire's total 1934 domestic refrigerator sales. ${ }^{40}$

Frigidaire's strategy of developing symbiotic relationships with franchisees proved particularly useful for this new generation of outlets, for which relying on economic muscle (Lamoreaux, 1998) to bring about compliance would be even less practicable than had been 
the case for their earlier, more specialised, retailers. Frigidaire's strategy towards these new outlets is illustrated by its department store policy. In 1932 Frigidaire established a Department Store Division and two years later it circulated a report showcasing the assistance provided to 43 department stores in 36 cities. Frigidaire's proposition to these stores included not just its strong brand name, but, "Active cooperation through a retail-store-minded factory and field, which provides the necessary help in combining specialty selling practices with store merchandising methods. $" 41$

Frigidaire encouraged department stores to have a separate refrigeration department that could participate in its selling campaigns, managed by someone trained in speciality selling, who was exclusively devoted to hiring, training, and directing the sales personnel. Meanwhile the salesmen, typically on a straight 8-10 percent commission, should spend at least half their time calling at prospects' homes (thus extending direct sales to department stores, which generally had no tradition of door-to-door selling). Frigidaire offered help with finding a competent specialist manager; supporting salesmen's training; and providing a package of advice and assistance regarding finding sales leads, marketing campaigns, etc. Some stores were also provided with specialist Frigidaire demonstrators to help with weekly sales meetings, while many engaged in co-operative advertising with Frigidaire. ${ }^{42}$ This assistance appears to have boosted sales; a 1934 report claimed that department stores using direct sales methods (44\% of Frigidaire department store franchisees) had average 1933 sales of $\$ 40,000$, while the remaining 56 percent had average sales of only $\$ 6,500 .^{43}$

Frigidaire also claimed that familiarity with their techniques provided positive spillovers with sales of the stores' other appliances. Some 31 of the 43 featured stores were said to be using Frigidaire's salesman's supervisory system (both for Frigidaires and the other major appliances they stocked), "based on the fact that close supervision of the actual selling man in his sales activity is the only effective way to produce real results." ${ }^{44}$ Thus their 
accumulated investment in supporting specialist dealers proved strongly transferrable to a new generation of franchisees, who sold refrigerators alongside a great many other lines, enabling Frigidaire to maintain its market lead in this changed environment.

\section{Conclusions}

This study of Frigidaire's distribution system, in the broader context of the inter-war U.S. durable goods sector, illustrates the contingent nature of the solutions employed, shaped by the characteristics of the product, the market, and competitive conditions (Perchard et. al., 2017). Even within GM, two very different approaches to franchising were developed in the 1920s, one based on opportunism (reflecting a concentrated market structure and the strong asset specificity of its dealerships) and another based on symbiotic relations - reflecting dealers' stronger exit option, given that they could redeploy their physical and human capital to either another refrigerator brand or a different durable. Thus, in order to understand distribution systems for durables in this era - and the associated evolution of hybrid business forms - it is necessary to have multiple case-studies, capturing differences in product, market, and competitive conditions. Different solutions were even developed within the same product category; for example, in vacuums Hoover retained the resale system, while Electrolux successfully developed a system based on directly-employed salesmen, with no retailer participation (Scott, 2019).

The Frigidaire case also illustrates the dangers of imposing a simple evolutionary franchising model, with an early phase of low services provision and an eventual shift to higher provision, without adequate historical evidence. Frigidaire developed many of the key techniques discussed in the modern franchising literature, to monitor franchisees, align franchisor and franchisee incentives, temper opportunism, transmit complex and tacit 
knowledge; and foster "buy-in" on the part of dealers and their employees. This system, based on extensive provision of business services and training, constituted a key transferrable competency that boosted the efficiency of Frigidaire's network - using Frigidaire's scale advantages to generate services such as sales planning, training, advertising, and market research, that could not be efficiently provided by individual retailers. It is not clear whether the key interdependencies that constituted the Frigidaire network's "system" - door-to-door selling supported by heavy advertising and planning; building symbiotic relationships with franchised distributors and retailers; developing strong, transferable competencies based around its selling strategy; and cementing dealer buy-in via a vigorous socialization strategy - were consciously planned or simply emerged in response to early challenges. However, all the key elements were in place by the late 1920s and constituted Frigidaire's basic selling system for the rest of the inter-war era.

Finally, this study casts doubt on the imperative for vertical integration during the early twentieth century, to coordinate throughput; develop efficient sales, consumer credit, after-sales service and similar downstream activities; and effectively respond to changing market and competitive conditions (Chandler, 1990: 28-31). It shows that that hybrid structures can fulfil all these functions, both in static and dynamic contexts, if networks are based on essentially relational, rather than formal, contracts. Frigidaire was able to adapt its franchising model during the 1930 s, to meet the needs of a market that was progressively more focused on over-the-counter sales by department stores and other general retailers. This contrasts sharply with the experience of Hoover, a more integrated firm - managing its own sales force - which rejected consultants' advice to renegotiate their contracts with retailers on the basis of a lower commission (reflecting the declining importance of retailer services), to combat the competitive threat from Electrolux's lower-cost distribution system (Scott, 2019). 
While Hoover's relationships with its retailers had become progressively formalised and arms-length (as the selling task was essentially conducted by Hoover), Frigidaire had maintained strong informal relations with its distributors and retailers, underpinned by the provision of services and training, together with a strong socialization strategy to "sell" its policies to its network, through building trust and social control and cohesion. This again reflects the importance of not treating hybrid business forms as a homogenous group, but instead focusing on the particular formal and informal controls and incentives employed, together with their implications for both static functionality and dynamic flexibility.

\section{References}

Akremi, A.E., Mignonac, K., Perrigot, R. (2010), 'Opportunistic behaviors in franchise chains. The role of cohesion among franchisees', Strategic Management Journal, 31, 930948.

Anon. (1936), 'Domestic refrigerator sales in America, 1935', Journal of Domestic Appliances, June, 11.

Anon. (1940), 'The nudes have it', Fortune Magazine, May, 73-104.

Anon. (1941), ‘Frigidaire men work for years on new improvements', Electrical Merchandising, April, 10-12.

Anon (1972), `50 years of statistics and history,' Merchandise Week, 104 (28 February), 21$54 \& 110-160$.

Ater, I., Rigbi, O. (2015), `Price control and advertising in franchising chains’, Strategic Management Journal, 36, 148-158.

Barthelemy, J. (2008), 'Opportunism, knowledge, and the performance of franchise chains', Strategic Management Journal, 29, 1451-1463. 
Biggart, N.W. (1989), Charismatic Capitalism. Direct Selling Organizations in America. University of Chicago Press: Chicago.

Bradach, J.L. (1997), 'Using the plural form in the management of restaurant chains', Administrative Science Quarterly, 42, 276-303.

Bradach, J.L. and Eccles, R.G. (1989), 'Price, authority, and trust: from ideal types to plural forms', Annual Review of Sociology, 15, 97-118.

Brown, E.H. (2005), The Corporate Eye. Photography and the Rationalization of American Commercial Culture 1884-1929, Johns Hopkins University Press, Baltimore.

Carney, M. and Gedajlovic, E. (1991), 'Vertical integration in franchise systems: agency theory and resource explanations', Strategic Management Journal, 12, 607-629.

Chandler, A.D. (1962), Strategy and Structure: Chapters in the History of the Industrial Enterprise. MIT Press: Cambridge, Mass.

Chandler, A.D. (1990), Scale and Scope. The Dynamics of Industrial Capitalism. Belknap: Cambridge, Mass.

Chassagnon, V. (2014), 'Beyond markets and hierarchies: an economic analysis of vertical quasi-integration', Revue de Philosophie Economique, 15, 135-165.

Clarke, S. (2003), 'Closing the deal: GM's marketing dilemma and its franchised dealers, 1921-41', Business History, 45, 60-79.

Combs, J.G., Ketchen, D.J., Hoover V.L. (2004a), `A strategic groups approach to the franchising-performance relationship', Journal of Business Venturing, 19, 877-897.

Combs, J.G., Michael, S.C., Castrogiovanni, G.J. (2004b), `Franchising: a review and avenues to greater theoretical diversity', Journal of Management. 30, 907-931. 
Darr, E.D., Argote, L., Epple, D. (1995), 'The acquisition, transfer, and depreciation of knowledge in service organizations: productivity in franchises', Management Science, $\mathbf{4 1}$, $1750-1762$.

Fershtman, C., Judd, K.L. (1987), ‘Equilibrium incentives in oligopoly’, American Economic Review, 77, 927-940.

Flyberg, B. (2006), ‘Five misunderstandings about case-study research’, Qualitative Enquiry, 12, 219-245.

Friedman, W.A. (2004), Birth of a Salesman. The Transformation of Selling in America. Harvard University Press: Cambridge, Mass.

Gantz, C. (2015), Refrigeration. A History. McFarland: Jefferson NC.

Hansen, M.T., (1999), `The search-transfer problem: the role of weak ties in sharing knowledge across organizational subunits', Administrative Science Quarterly, 44, 82-111.

Hendry, J. (2002), `The principal's other problems: honest incompetence and the specification of objectives', Academy of Management Review, 27, 98-113.

Hoover, R, Hoover, J. (1993), An American Quality Legend. McGraw-Hill: New York.

Kipping, M, Usdiken, B., (2014), 'History in organization and management theory: more than meets the eye,' Academy of Management Annals, 8, 535-588.

Kwolek-Folland, A. (1994), Engendering Business. Men and Women in the Corporate Office 1870-1930. Johns Hopkins, Baltimore.

Lafontaine, F. (1992), ‘Agency theory and franchising: some empirical results', Rand Journal of Economics, 23, 263-283.

Lafontaine, F, Slade M.E. (1997), 'Retail contracting: theory and practice’, The Journal of Industrial Economics', 45, 1-25. 
Lamoreaux, N.R. (1998), 'Partnerships, corporations, and the theory of the firm,' American Economic Review1, 88, 66-71.

Lamoreaux, N.R., Raff, D.M.G, Temin, P. (2003), `Beyond markets and hierarchies: towards a new synthesis of American business history,' American Historical Review, 108, 404-433.

Maclean, M, Harvey C, Clegg S.R. (2017), 'Organization theory in business and management history: present status and future prospects,' Business History Review, 91, 457-481. Macneil, I. (1978), `Contracts: adjustment of long-term economic relations under classical, neo-classical, and relational contract law', Northwestern Law Review, 72, 854-906.

Oxenfeldt A.R., Kelly A.O. (1969), 'Will successful franchise systems ultimately become wholly-owned chains?', Journal of Retailing, 44, 69-83.

Penrose, E.E. (1959), The Theory of the Growth of the Firm. Wiley: New York.

Perchard, A., MacKenzie, N, Decker, S, Favero, G. (2017), 'Clio in the business school: historical approaches in strategy, international business and entrepreneurship', Business History, 59, 904-297.

Quinn, T.K. (1953), Giant Business. Threat to Democracy. Exposition: New York. Rubin, P.H. (1978), 'The theory of the firm and the structure of the franchise contract', The Journal of law and Economics, 21, 223-233.

Scott, P., (2017), The Market Makers. Creating Mass Markets for Consumer Durables in Inter-war Britain. Oxford University Press: Oxford.

Scott, P. (2019), 'Rethinking business models in the Great Depression. The failure of America’s Vacuum Cleaner Industry,' Business History Review, 93, 319-348.

Scott, P. (forthcoming), “"Forced Selling”, Domesticity, and the Diffusion of Washing-Machines in Inter-War America,' Journal of Social History. 
Scott, P, Walker, J. (2016), ‘Bringing radio into America’s homes: marketing new technology in the Great Depression', Business History Review, 90, 251-276.

Slade, M.E. (1998), 'Motives for vertical separation: evidence from retail gasoline markets', Journal of Law, Economics, \& Organization, 14, 84-113.

Tedlow, R.S. (1990), New and Improved. The Story of Mass Marketing in America. Heinemann: Oxford.

Tirole, J. (1988), The Theory of Industrial Organisation. MIT Press: Cambridge, Mass.

Turner, K.L. and Makhija, M.V. (2006), `The role of organizational controls in managing knowledge', Academy of Management Review. 31, 197-217.

United States, Temporary National Economic Committee (1940), Investigation of Concentration of Economic Power. Monograph No. 1. Price Behavior and Business Policy (Washington: USGPO).

Williamson, O.E. (1988), `The logic of economic organization’, Journal of Law, Economics, and Organization, 4, 65-93.

Williamson, O.E. (1991), 'Comparative economic organization: the analysis of discrete structural alternatives', Administrative Science Quarterly, 36, 269-296.

Williamson, O.E. (2003), 'Examining economic organization through the lens of contract', Industrial and Corporate Change, 12, 917-942.

Zucker, L. (1986), ‘Production of trust: institutional sources of economic structure', 18401920, Research in Organizational Behavior, 8, 53-111.

Zunz, O. (1990), Making America Corporate 1870-1920. University of Chicago Press, Chicago. 
Table 1: Frigidaire household refrigerator sales and market share, 1926-1941

\begin{tabular}{|r|c|r|r|r|}
\hline Year & \multicolumn{2}{|c|}{ Frigidiaire sales } & \multicolumn{2}{c|}{$\%$ of national unit sales } \\
\hline & Units & \$ (million) & Electrical & Mechanical \\
\hline 1926 & 70,071 & 25 & n.a. & 30.5 \\
\hline 1927 & 117,046 & 47 & n.a. & 28.2 \\
\hline 1928 & 163,937 & 47 & n.a. & 27.8 \\
\hline 1929 & 308,733 & 77 & 39.7 & 37.3 \\
\hline 1930 & 207,703 & 55 & 26.3 & 24.3 \\
\hline 1931 & 227,823 & 53 & 25.1 & 23.0 \\
\hline 1932 & 174,085 & 33 & 21.8 & 19.4 \\
\hline 1933 & 224,246 & 40 & 22.1 & 18.7 \\
\hline 1934 & 242,325 & 45 & 18.9 & 17.3 \\
\hline 1935 & 300,976 & 52 & 19.2 & 17.4 \\
\hline 1936 & 443,940 & 77 & 22.3 & 20.2 \\
\hline 1937 & 503,574 & 94 & 21.8 & 19.6 \\
\hline 1938 & 259,103 & 48 & 20.7 & 18.0 \\
\hline 1939 & 338,259 & 61 & 17.8 & 15.8 \\
\hline 1940 & 621,730 & 91 & 23.9 & 21.7 \\
\hline 1941 & 722,397 & 112 & 20.6 & 19.0 \\
\hline
\end{tabular}

Sources: years 1926-28, Kettering, Frigidaire, 79.10.1.164, `Frigidaire and industry unit sales 1926-54', (n.d., c. 1955); 1929-41, ibid, 79.10.1.41A, statistical tables for T. R. Shellworth, 'Report on Frigidaire's Development', (1950), statistical tables, p. 24.

Note: "Mechanical" includes electric and other powered refrigerators, e.g. by gas, or kerosene. 
Figure 1: Diffusion of electric washing machines, vacuums, and refrigerators, 1922-1940 (percentage of wired households)

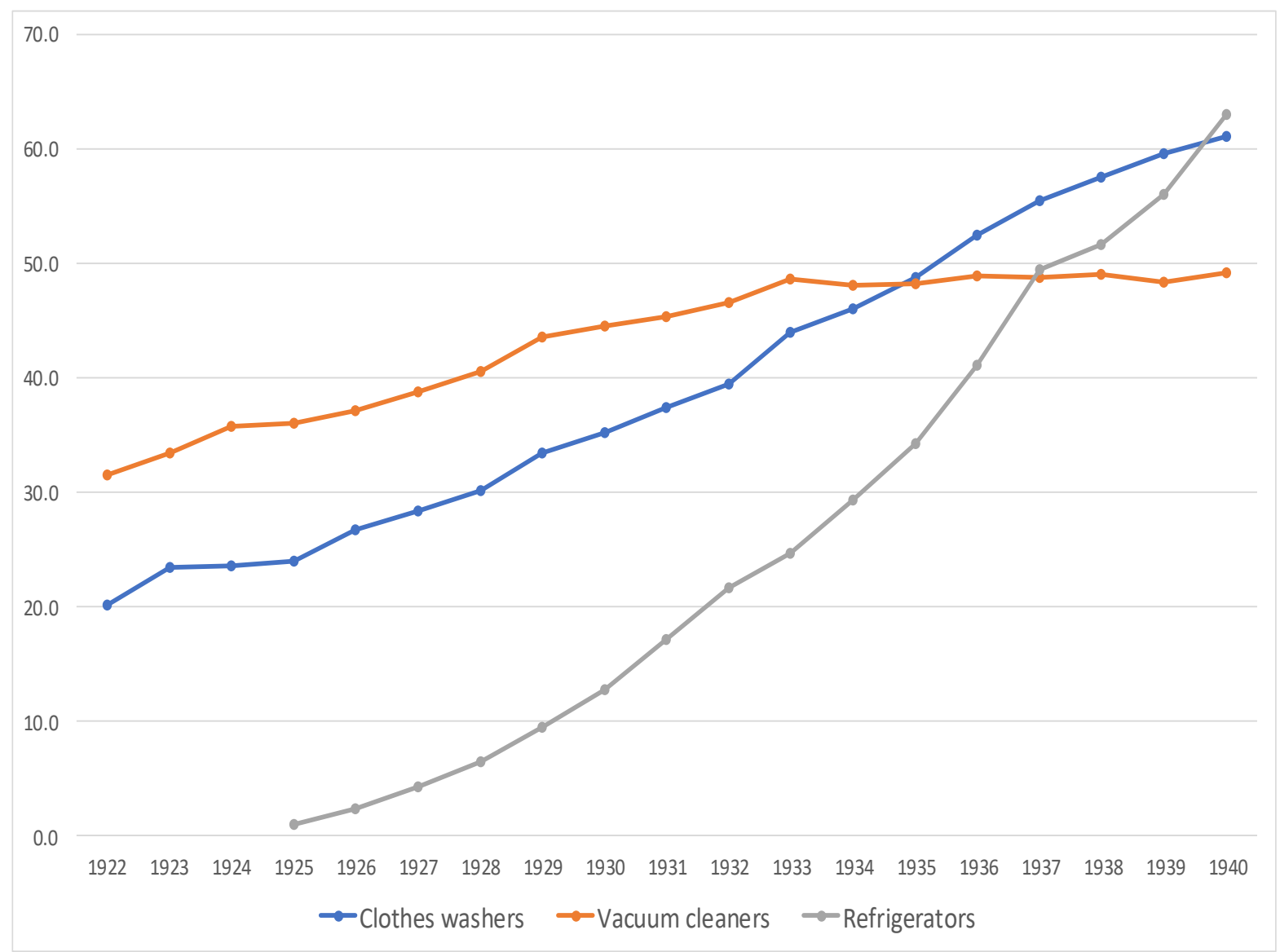

Source: Anon, 1972.

Notes: Data exclude second-hand sales (except for machines reconditioned and re-sold by their original manufacturers). 
Figure 2: U.S. household electrical refrigerator sales seasonality, 1935 (percentage of average monthly sales).



Source: Anon., 1936.

\footnotetext{
${ }^{1}$ Misci Museum, Schenectady, NY, Gerald Swope papers, Box 1, Folder 115-3 I, G.E. President's reports, 5 Feb. 1932 and Dec. 30 ${ }^{\text {th }}$ 1932; Centre for Business History, Stockholm, Electrolux archive, F4G: 30, Servel U.S. refrigerator sales, 1926-30, n.d., c. 1931; F4G: 38, similar data, 1931-35, n.d., c. 1936.

${ }^{2}$ Kettering University Archives, Flint, Mi, Frigidaire Collection [hereafter Kettering, Frigidaire] 79.10.5.22,

"General Motors and the household appliance industry" report, March 1936, pp. 2-6.

${ }^{3}$ Kettering, Frigidaire, 79.10.2.17, "Notes on General Electric competition” folder, memo by Mr Newell, 1 June 1929.
} 
${ }^{4}$ Wright State University Library, Special Collections and Archives, unpublished draft history of Frigidaire, 1964 (hereafter Wright State, Frigidaire history), 1A/2, Frigidaire moves to Dayton chapter, pp. 1-3.

${ }^{5}$ Wright State, Frigidaire history, A2/2, Salesmanship chapter, p. 21.

${ }^{6}$ Ibid, p. 42.

${ }^{7}$ Ibid, pp. 39-40.

${ }^{8}$ Kettering, Frigidaire, 79.10.1.41B, T. R. Shellworth, “Report on Frigidaire's development," Section III, p. 1.

${ }^{9}$ Kettering, Frigidaire, 79.10.1.39, T. R. Shellworth, "The history of Frigidaire ,"1949 version, Part VII.

"Frigidaire sales and advertising practices," 1949.

${ }^{10}$ Kettering, Frigidaire, 79.10.11.50, General sales promotion plan for 1931, 24 Nov. 1930.

${ }^{11}$ Hagley Museum Library \& Archives, Wilminghton, Delaware, 2069/9/16, Victor Talking Machine Co. field survey, 1926-27. Reports of interview with Mr L. Boulware, General Sales Manager, Syracuse Washing Machine Corp., $27^{\text {th }}$ April 1927.

${ }^{12}$ Kettering, Frigidaire, 79.10.2.16, "Dealership operation," points covered in talk by C.W. Martin, Branch Manager, Flint, Michigan, at Branch Convention, 15 June 1928.

${ }^{13}$ During this period consumer durables direct sales people and managers (with the exception of canvassers) were uniformly male.

${ }^{14}$ Kettering, Frigidaire, 79.10.11.166. Frigidaire dealer's agreement, 1933.

${ }^{15}$ Kettering, Frigidaire, 79.10.2.16, 'Dealership operation,' points covered in talk by C.W. Martin, Branch Manager, Flint, Michigan, at Branch Convention, 15 June 1928.

${ }^{16}$ Kettering, Frigidaire, 79.10.11.40. Frigidaire supervisory and sales activity accounting plan (1930).

${ }^{17}$ Kettering, Frigidaire, 79.10.11.40. Frigidaire supervisory and sales activity accounting plan (1930).

${ }^{18}$ Kettering, Frigidaire, 79. 10.51. "What department stores have accomplished to date with Frigidaire', report, 1934.

${ }^{19}$ Kettering, Frigidaire, 79.10.11.50, General sales promotion plan for 1931, 24 Nov. 1930; 79.10.5.8,

"Suggestions for the selection of Frigidaire salesmen," booklet, 1928, p. 5.

${ }^{20}$ Kettering, Frigidaire, 79.10.11.116, Frigidaire “Every man get a man” broadside, $26^{\text {th }}$ Jan. 1933.

${ }^{21}$ Wright State, Frigidaire history, A2/2, salesmanship chapter, p. 45.

${ }^{22}$ Kettering, Frigidaire, 79.10.2.15B. 'Demonstrating Frigidaire,' manual, n.d., c. mid-1920s, pp. 13-15.

${ }^{23}$ Kettering, Frigidaire, 79.10.1.106, "The Standard Plan of selling Frigidaire," 1934, 9-15.

${ }^{24}$ Kettering, Frigidaire, 79.10.107, Selling with Proof (1936), 52. 
${ }^{25}$ Wright State, Frigidaire history, A2/2, Salesmanship chapter, p. 34.

${ }^{26}$ Kettering, Frigidaire, 79.10.11.162, 1933 sales budget documents, c. Jan. 1933.

${ }^{27}$ Kettering, Frigidaire, 79.10.5.11, Opportunities in a Growing Business, dealers' booklet (1930), p. 34.

${ }^{28}$ Ibid.

${ }^{29}$ Kettering, Frigidaire, 79.0.2.16B, “How to sell Frigidaire in the winter', brochure, 1928.

${ }^{30}$ Kettering, Frigidaire, 79.10.5.18, "Selling Frigidaire on the meter-ice purchase plan," booklet, (1935), p. 2.

${ }^{31}$ Kettering, Frigidaire, 79.10.2.16, 'Dealership operation,' points covered in talk by C.W. Martin, Branch Manager, Flint, Michigan, at Branch Convention, 15 June 1928.

${ }^{32}$ Kettering, Frigidaire, 79. 10.51. "What department stores have accomplished to date with Frigidaire', report, 1934.

${ }^{33}$ Wright State, Frigidaire history, A2/2, Salesmanship chapter, p. 26; Kettering, Frigidaire, 79.10.5.8 \&

79.10.5.10, various issues of Frigidaire Field News, 1928-29.

${ }^{34}$ Kettering, Frigidaire, 79.10.5.11, "Opportunities in a growing business," dealers' booklet (1930), p. 37.

B.T.U. stands for British Thermal Unit (a traditional unit of heat, used to measure refrigerator power).

${ }^{35}$ Kettering, Frigidaire, 79.10.5.8, Frigidaire Field News, Vol. VII, No. 76, 18 Sept. 1928; 79.10.5.10, various issues of Frigidaire Field News for 1929.

${ }^{36}$ Wright State, Frigidaire history, A2/2, salesmanship chapter, pp. 16-18; Kettering, Frigidaire, 79.10.1.52,

Frigidaire report on Frigidaire household business, for General Motors, April 1937.

${ }^{37}$ Wright State, Frigidaire history, A2/2, Salesmanship chapter, 16-18.

${ }^{38}$ Kettering, Frigidaire, 79.10.2.16, 'Dealership operation,' points covered in talk by C.W. Martin, Branch Manager, Flint, Michigan, at Branch Convention, 15 June 1928.

${ }^{39}$ Kettering, Frigidaire, 79.10.1.52, Report, "General operating trends", 18 Oct. 1935.

${ }^{40}$ Ibid.

${ }^{41}$ Kettering, Frigidaire, 79.10.11.120, “Frigidaire merchandising plan,” 1932, p. 1.

${ }^{42}$ Kettering, Frigidaire, 79. 10.51. "What department stores have accomplished to date with Frigidaire', report, 1934.

${ }^{43}$ Ibid..

${ }^{44}$ Ibid. 